\title{
Stock Market Reaction to Monetary Policy Modifications: Evidence from an Emergent Market
}

\author{
Cordelia Onyinyechi Omodero
}

Dorcas Titilayo Adetula

\author{
Kingsley Adeyemo
}

Department of Accounting,

DOI: https://doi.org/10.36941/ajis-2021-0o64

\section{Abstract}

This study evaluates the stock market reaction to monetary policy modifications in an emerging market using Nigeria as a case study. Due to the crucial role the stock market plays in the global economy and finance, it becomes an attraction for most researchers and policymakers who try to find a basis for its smooth operation. This study uses data that cover a period from 1998 to 2018 to establish what the position is in recent times empirically. The data are collected on all share index, money supply, interest rate and exchange rate. The multiple regression results provide evidence that the money supply has a significant favourable influence on the all-share index. In contrast, the interest rate has an immaterial harmful effect on the stock market output. However, the result indicates that the exchange rate affects the stock market performance negatively, but the effect is insignificant. Based on these findings, the study suggests pilot test running of all monetary policy amendments by the monetary authority in the country before full implementation. The government should encourage the CBN to cut down on interest rate and avoid all policies that will lead to a crash in the Nigerian stock market.

Keywords: Nigerian Stock Market, lending ratio, financial strategies, currency quantity, conversion rate

\section{Introduction}

The stock market provides a platform for the exchange of shares and general marketability of stocks. A stock market is an equity market where individual and institutional investors buy and sell shares. The stock market is a unique market that deals with products that have volatile prices and respond readily to economic stimuli. The securities that are traded in the stock market have the nature that is so much influenced by monetary policy announcements, both globally and nationally. These monetary policy surprises have made stock markets so unpredictable and stock prices so unstable that both the developed and the emerging markets are found in the same saga. There are varying monetary policy tools used by the Central Banks of nations to manipulate the economy through the determination of credit accessibility and the amount of money that should be in circulation within a specified period. This study verifies the impact of monetary policy shocks on the stock market in Nigeria. The selected monetary policy devices used in this study include the money supply $\left(\mathrm{M}_{2}\right)$, interest rate and exchange rate. Studies have shown that interest rate hurts the stock market output (Okpara, 2010; Zare, Azali \& 
Habibullah, 2013; Gali \& Gambetti, 2013; Ali, 2014; Hojat, 2015; Nwokoye \& Otu, 2018; Omodero, 2020). Contrarily, the study of Maroz (2020) discovered a significant positive relationship between stock market returns and the interest rates. The reviews of (Jamil \& Ulla, 2013; Chukwuemeka, 2018) provide evidence that exchange rate policies through Central Banks can assist investors in the projection of stock market volatility. Some studies also examined the impact of money supply on the stock market (Nofeldt, 2014; Hojat, 2015; Nwokoye \& Otu, 2018; Omodero, 2020) and found a positive correlation between the money supply and stock market productivity.

Outside these three variables selected for this study, the Central Bank also uses some other tools such as reserve ratio for banks and open market operations as deemed necessary from time to time (Teja, Tejaswi, Madhavi \& Ujwala, 2013). Pilinkus (2010) submits that the stock market helps a great deal in highlighting the state of a country's economy, such that if stock prices start to decline, it reflects economic depression while growth in stock prices is evidence that the anticipated economic growth is achieved. The interest rate changes affect the stock market through dwindling of stock investment. When the interest rate is high, investors tend to reduce their investment commitment due to the high cost of finance. The stocks at this point, become less attractive and results in the low stock market output. However, a low-interest rate helps to boost the stock market. The global monetary policy modification reflects in the exchange rate fluctuations. When the exchange rate is very high, investment in stock shrinks while the reduced rate of exchange increases investment in shares. Generally, the money supply determines the level of money available for investors to spend. When the money in circulation is not at equilibrium, investors find it challenging to invest the little that is meant for household usage. The point is that monetary powers are encouraged to ensure that the money supply matches the level of economic activities in an economy.

\section{Literature Review}

\subsection{Theoretical framework}

The theory underlying this study is the Efficient Market Hypothesis (EMH) by Fama (1970). The EMH is a hypothesis which states that asset prices reflect all available information. The implication is that the costs of stocks indicate all economic circumstances surrounding them, which include monetary policy pronouncements showing the variations in the monetary policy instruments. Fama (1970) classified the empirical test of efficiency into weak-form, semi-strong form and strong form. The weak form provides information on the historical prices only, and the semi-strong way includes both the historical prices and the publicly available information which invariably will consist of the effect of the monetary policy announcements. The strong form highlights the historical prices, publicly available data and insider information.

\subsection{Empirical review}

Zare, Azali and Habibullah (2013) inspected the lop-sided response of the stock market to monetary policy over bull and bear market periods in ASEAN5 countries (Malaysia, Indonesia, Singapore, the Philippines and Thailand) by employing pooled mean group (PMG) technique. The study utilized Markov-switching models and law-based non-parametric methodology to classify the bull and bear markets. The monthly data used for model estimation ranged from January1991to December 2011. Hence the results indicated that an increase in the interest rate had a more substantial long-run impact on stock market variability in the bear markets than it was observed in the bulls market. Hojat (2015) investigated the effect of changes in monetary policy instruments which comprised money supply (M2), federal funds rate (FFR) and national funds futures (FFF) on the rate of return of the entire stock market. The study covered a period from 2005 to 2015 using ex post facto research design and multiple regression techniques. The multiple regression exhibited a progressive influence of market rate of return and company size, a constructive reasonableness impact of $\mathrm{M} 2$, and a harmful pragmatism and arbitration consequence of FFR and FFF on the predictable quality of returns of the quoted companies. 
Rifat (2015) used several econometric models to examine the short-run and long-run relationship between monetary policy tools and the stock price index in Bangladesh. The results for all multivariate models applied in the study were homogenous and showed a weak relationship between the stock price index and the monetary policy devices. Trung et al. (2016) used the GJR-GARCH model and ARDL to appraise the impact of monetary policy on the Vietnam stock market index from 2006 to 2015. The outcome of the study demonstrated that the monetary policy tools, which included interest rate, exchange rate and required reserve ratio exerted negative impacts on stock price in the long term. The findings further revealed that both negative and positive market shocks resulted in stock price variations in Vietnam stock market. Ekong and Onye (2016) tested the reaction of the stock market towards monetary policy shocks using market liquidity, all share index and stock market turnover as proxies for stock market output. The study applied a structural vector auto-regressive method which revealed that money supply and interest rate were more productive in influencing the stock market than the monetary policy rate.

Atgur and Yigit (2017) assessed the impact of monetary policies on the Borsa Istanbul (BIST) stock market in Turkey from 2006 to 2016 using Johansen Co-integration and Granger Causality test methods. Based on the result from Johansen Co-integration test, there was a long-run relationship. While the Granger Causality test revealed the existence of a strong relationship between the BIST stock market price and return indices and the monetary policy tools namely: money supply $\left(\mathrm{M}_{2}\right)$ and deposit interest rate (DIR). Thus, the findings established that monetary policy in Turkey had a significant impact on the stock market. Vladimír (2017) observed the effect of money supply on the stock market through the portfolio equilibrium network as a diffusion device of monetary policy. The primary aim of the study was to provide statistical evidence on the influence of money supply on the US stock market. Johansen's co-integration approach and vector error correction model were used to produce an empirical proof which showed that the money supply had an impact on the valuation of S\&P 500 index with 6 months lag. Pierre and Danillo (2017) evaluated the role of sectoral co-movement in transmitting monetary policy shocks on the stock market. The study initiated factor-augmented vector autoregressive model with mixed regime-switching factor loadings, represented as MS2-FAVAR, which tolerated mutual appraisal of the level of variation in stock returns of sectors and the transmission of monetary policy shocks on the stock market. The study found evidence that the impact of monetary policy shocks on stock returns became significantly more intense when industries were experiencing a robust level of co-movement.

Helmut and Aleksei (2018) used co-integrated structural vector autoregressive model to examine the relationship between monetary policy and the stock market in Europe. The study found that variation in the contractionary monetary policy resulted in long term decline in stock prices. Chukwuemeka (2018) determined the correlation between monetary policy and the performance of the Nigerian capital market using the ordinary least squares (OLS) and other relevant econometric models. The findings revealed that interest rate, exchange rate, monetary aggregate and monetary policy rate had a favourable material correlation with market capitalization. In contrast, the Treasury bill rate had an undesirable and noteworthy affiliation with market capitalization. The study further indicated that the monetary policy rate, monetary aggregate and exchange rate had a positive relationship with market turnover. In contrast, the Treasury bill rate and interest rate had a negative and meaningful connection with market turnover. Nwokoye and Otu (2018) considered the effect of monetary policy on the development of the stock market in Nigeria. The study covered a period from 1981 to 2015 and made use of co-integration test and vector error correction method. The study found that money supply impacted positively and significantly on stock market development. On the contrary, the interest rate exerted a negative influence on the stock market.

Anaele and Umeora (2019) studied the relationship between monetary policy and the Nigerian capital market performance from 1986 to 2017 . The monetary policy tools employed by the study included economic policy rate, cash reserve ratio, liquidity ratio and loan to deposit balance while using all share index as a proxy for capital market performance. The result from the auto-regressive distribution lag (ARDL) regression method indicated that the monetary policy rate, cash reserve ratio and loan to deposit ratio adversely and considerably interrelated with the capital market output. At the same time, the liquidity ratio had an affirmative correlation with capital market productivity. Prabu, 
Indranil and Ray (2019) examined the impact of both national and US monetary policy pronouncements on the Indian Stock indices at a sectoral level. The US quantifiable enablement was established to have a remarkable influence on some sectors. The study further discovered the contradictory effect of monetary policy proclamations on sectoral stock indices with proof of policy shocks having a consequential impact on a few sectors. Santanu and Garg (2019) investigated the effect of monetary and macroeconomic policy on Indian stock market using data that spanned from 2004 to 2016. The study adopted Vector auto-regression model, and the result indicated that the monetary policy shocks significantly impacted the stock market more than the other macroeconomic shocks.

\section{Materials and Methods}

This study analyzes the stock market reaction to monetary policy shocks in Nigeria. The research design employed is the expo facto, while the secondary form of data utilized span from 1998 to 2018. The study carried out relevant diagnostic tests while using the ordinary least squares (OLS) multiple regression techniques for analysis to avoid convolution and lack of clarity in providing the necessary empirical evidence targeted by the study. The World Bank Economic Indicators and CBN Numerical Report of 2018 are the sources of data for this examination. Data are expressed with logarithm values since some are collected in local currency while some others are figures expressed in percentages as at the time of collection.

\subsection{Description of model for the study}

Mathematical narrative of model for this study is as follows:

ASI $=f(M S P, I N T, X G R)$

LOGASI $=\beta_{o}+\beta_{1}$ LOGMSP $+\beta_{2}$ LOGINT $+\beta_{3}$ LOGXGR $+\mu$

Where:

ASI = All Share Index; MSP = Money supply;

$\mathrm{INT}=$ Interest rate; $\mathrm{XGR}=$ Conversion ratio

$\beta_{0} \quad=$ Perpetual;

$\beta_{1}-\beta_{3}=$ Relapse measurements;

$\mu \quad=$ Inaccuracy stint.

A priori, we expect: $\beta 1>0, \beta_{2}>0, \beta_{3}>0$.

\section{Information Breakdown as Well as Clarification}

\subsection{Trend analysis}

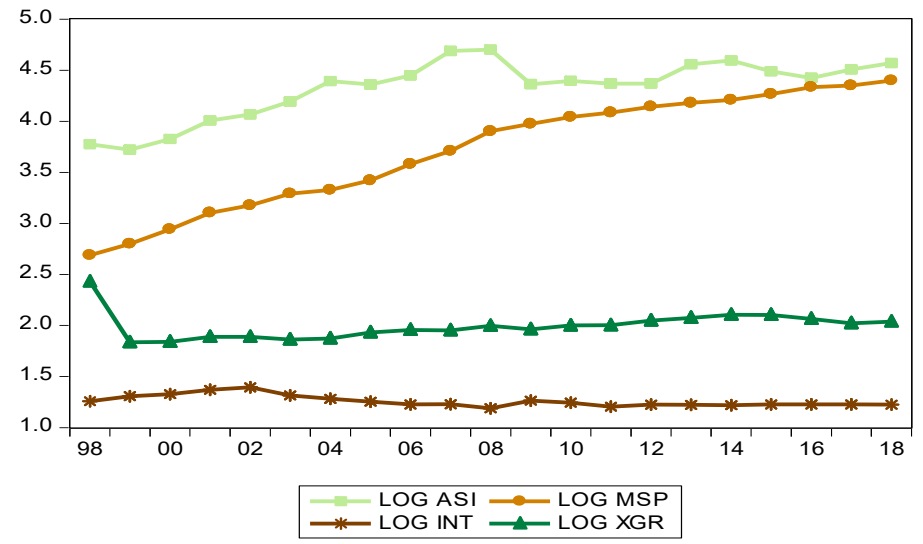

Figure 1:

Source of data: World Bank Economic Indicators and Central Bank of Nigeria Statistical Bulletin 
Figure 1 above shows the trend of data on the all-share index (ASI), money supply (MSP), interest rate (INT) and exchange rate (XGR). From figure 1, the graph shows that the money supply moves in the same direction with the all-share index, which represents the stock market level of productivity. The interest rate is far below the acceptable limit, and the exchange rate does not also have a proper position. The graphical representation shows that the money supply affects the all-share index positively while the other monetary policy tools are in the opposite direction. The implication is that instruments used by the monetary authorities affect all share index positively or negatively when there are variations.

Table 1: Stability test

Ramsey RESET Test

Specification:LOG_ASI LOG_MSP LOG_INT LOG_XGR C

\begin{tabular}{lccc}
\hline & Value & Df & Probability \\
\cline { 2 - 4 } F-statistic & 1.709645 & $(1,16)$ & 0.2095
\end{tabular}

Table 1 above shows the result of the stability test using the Ramsey RESET Test. The null hypothesis supports the existence of a linear relationship in the regression model. The work reveals that there is stability in the data set used in this study as the p-value of $0.2095>0.05$ level of significance. Thus, there is an absence of nonlinear relationships in the developed linear regression model.

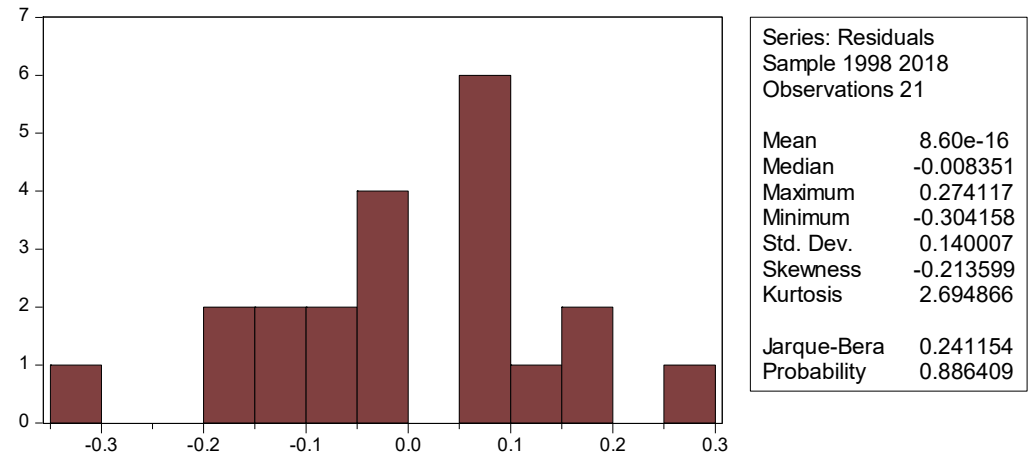

Figure 2: Normality test

Source: Output from e-views version 9

Figure 2 shows a normal distribution of the data set based on the result of the Jarque-Bera $(0.241154$; $\mathrm{p}$ value $0.886>0.05$ ). The Kurtosis is approximately 3 , and the standard deviation is below the mean value, though there is a negative skewness.

Table 2: Multicollinearity test

Variance Inflation Factors

Date: $12 / 30 / 19$ Time: 16:22

Sample: 19982018

Included observations: 21

\begin{tabular}{cccc}
\hline \hline & Coefficient & Uncentered & Centered \\
Variable & Variance & VIF & VIF \\
\hline \hline LOG_MSP & 0.008107 & 103.8312 & 2.157580 \\
LOG_INT & 1.041142 & 1506.172 & 2.688531 \\
LOG_XGR & 0.092171 & 335.1480 & 1.371254 \\
C & 3.574025 & 3254.609 & NA \\
\hline \hline
\end{tabular}

Source: Author's computation, 2020 
The usage and interpretation of a multiple regression model hinge on the supposition that the independent variables are not interconnected (Australian Property Institute, 2015). Table 2 above provides a test for multicollinearity, which occurs when two or more independent variables strongly intersect in explaining the same element. It merely implies that there is a correspondence in measuring the same quality among them. The study used the Variance Inflatory Factor (VIF) to identify the interconnection among the independent variables. The VIF is used to quantify the rate at which an economic element variance is increasing. The rise of any economic factor is attributed to the presence of interconnectivity among the elements in a study. According to Gujarati \& Porter (2009), the Variance Inflatory Factor (VIF) explaining this scenario should not be more than 10. Where the value surpasses 10 , there is a suggestion to eliminate the affected variables by reviewing the data set again. So, to harmonize the distribution, the affected independent variable has to be stopped. However, in this study, the VIF values of all the independent variables are less than 10. Therefore, there is an absence of multicollinearity.

Table 3: Regression result

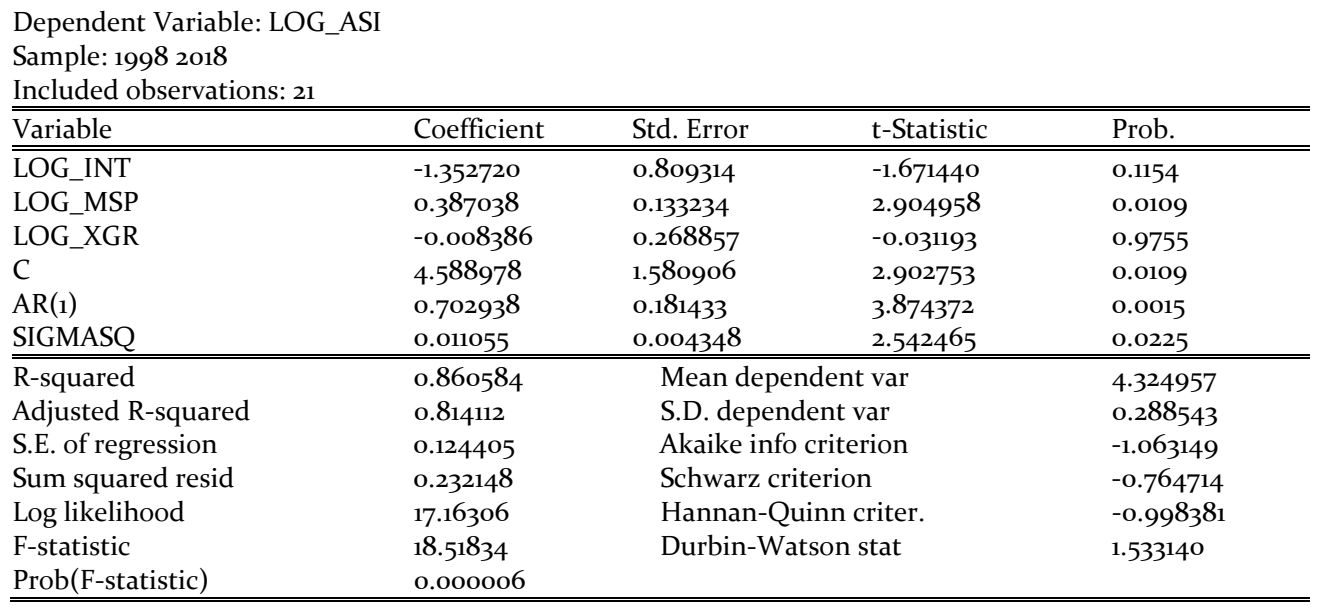

Source: Author's computation, 2020

The regression result in table 3 above provides evidence that ASI and the monetary policy instruments employed in this study have a robust correlation. The correlation value is $92.7 \%$ which the square root of R-squared. In the same vein, the R-squared value is $86.0 \%$ which shows the extent to which MSP, INT and XGR explain the variations in the ASI. The result confirms the fact that monetary policy modifications determine the stock market performance to a large extent. Thus, it follows that the remaining $14 \%$ is not included in the model formulated for this study. The Durbin-Watson is within the acceptable limit. The F-Statistic is 18.518 while the p-value is $0.000<0.05$. This result indicates that the model is a good fit and statistically significant. It is also an indication that the independent variables collectively affect the ASI.

The effects of the individual variables are tested with the t-statistics. From table 3 above, MSP tstatistic is 2.905 with a p-value of $0.01<0.05$. The result implies that the money supply has a substantial favourable influence on ASI. INT t-statistic is -1.671while the p-value is $0.011>0.05$. This result indicates that the interest rate has an insignificant harmful effect on ASI. XGR t-statistic is -o.031 with the p-value of $0.97>0.05$ level of significance. The result provides evidence that the exchange rate has an immaterial adverse effect on ASI. 


\section{Conclusion and Recommendations}

\subsection{Conclusion and research implication}

The study investigates the stock market reaction to monetary policy surprises in Nigeria. From the regression result in table 3 , the money supply has a significant favourable influence on all share price index. In contrast, the interest rate has an inconsequential negative impact on stock market performance. Although the exchange rate has an insignificant negative effect, the effect is immaterial in this study. The outcome of this research will provide the investment community with both individuals and organizations the bases for proper and rational investment decision making and capital rationing determinations, especially during economic downturns. The findings will also assist the monetary policy authority in their assessment of stock market response to monetary policy shocks to avoid subsequent stock market collapse and general fall in the value of stocks that are traded in the Nigerian stock market.

\subsection{Recommendation}

Based on the outcome of this study, the monetary powers in Nigeria has the responsibility to regulate the outflow of money and checkmate the interest rate to encourage investment in stocks. Therefore, it is recommended that the cost of obtaining credit by investors should be reduced to boost the stock market productivity. The money supply should be stable and correspond with economic activities. The implication is that the money in circulation should always meet the investment demands of the economy. The Central Bank of Nigeria should endeavour to come up with strategies to improve the value of the local currency. When the exchange rate is too high, it renders the domestic currency relatively useless, and the local investors may not find specific securities attractive for investment. Generally, since the stock market is vulnerable to monetary policy changes, the government needs to encourage the financial authority in the country to avoid all economic policies that will lead to a collapse of the stock market. In that case, this study suggests a preliminary test run of all new policies that affect stock prices and other stock market concerns before full implementation.

\section{Acknowledgement}

The authors appreciate the funding of this paper by Covenant University Ota, Ogun State, Nigeria.

\section{References}

Ali, H. (2014). Impact of Interest Rate on Stock Market; Evidence from Pakistani Market. Journal of Business and Management, 16(1), 64-69. Available at: https://pdfs.semanticscholar.org/6b2d/5732164110094549d3ee99761cdıd57aeb3f.pdf.

Anaele, S.C. \& Umeora, C.E. (2019). Monetary policy and the performance of the Nigerian Capital Market (19862017). International Journal of Research in Engineering Science and Management, 2(7), 59-72.

Atgur, M. \& Yigit, F. (2017). Causality analysis of the impact of monetary policy on stock markets: The case of Turkey. Journal of Knowledge Management, Economics and Information Technology, 7(4), 1-20.

Australian Property Institute (2015). The valuation of real estate. $2^{\text {nd }}$ edition. Canberra, Australia: Appraisal Institute.

Chukwuemeka, A. (2018). Monetary policy and the performance of Nigeria capital market: A time variant analysis. European Journal of Accounting, Auditing and Finance Research, 6(6), 22-43. Available online at: http://www.eajournals.org/wp-content/uploads/Monetary-Policy-and-the-Performance-of-Nigeria-CapitalMarket.pdf.

Ekong, C.N. \& Onye, K.U. (2016). Essay on stock market performance and dynamic reactions to monetary policy shocks in Nigeria. Munich Personal RePec Archive, MPRA Paper No. 88319. Available at: https://mpra.ub.unimuenchen.de/88319/1/MPRA_paper_88319.pdf. 
Fama, E.F. (1970). Efficient capital markets: A review of theory and empirical work. The Journal of Finance, 25(2), 383-417. DOI: $10.2307 / 2325486$.

Gali, J., \& Gambetti, L. (2015). The Effects of Monetary Policy on Stock Market Bubbles: Some evidence. Nber Working Paper Series.

Gujarati, D.N., \& Porter, D.C. (2009). Basic Econometrics (5th Ed.). Boston: McGraw-Hill Irwin. ISBN 978-o-o7337577-9.

Helmut, L., \& Aleksei, N. (2018). The relation between monetary policy and the stock market in Europe. Econometrics, 6(3), 1-14. DOI: 10.3390/econometrics6030036.

Hojat, S. (2015). The impact of monetary policy on the stock market. Doctoral Dissertation Submitted to the College of Management and Technology, Walden University. Available at: https://scholarworks.waldenu.edu/cgi/viewcontent.cgi?article=2602\&context=dissertations

Jamil, M., \& Ulla, N. (2013). Impact of Foreign Exchange rate on stock prices. Journal of Business and Management, 7(3), 45-51. Available at: http://www.iosrjournals.org/iosr-jbm/papers/Vol7-issue3/Go734551.pdf?id=5284.

Marozva, G. (2020). The effects of monetary policy on stock market returns and volatility: Evidence from South Africa. Academy of Accounting and Financial Studies Journal, 24(3), 1-11.

Nofeldt, O. (2014). The effects of Monetary Policy on Stock Market Returns. UMEA University, pp. 1-34. Available online at: http://www.diva-portal.org/smash/get/diva2:790845/FULLTEXTo1.pdf.

Nwokoye, E.S. \& Otu, E. (2018). Impact of monetary policy on stock market development: Implication for the Nigerian Economy. International Journal of Development and Economic Sustainability, 6(4), 29-50. Available at: http://www.eajournals.org/wp-content/uploads/Impact-Of-Monetary-Policy-on-Stock-Market-DevelopmentImplications-for-the-Nigerian-Economy.pdf.

Okpara, G.C. (2010). Monetary policy and stock market returns: Evidence from Nigeria. Journal of Economics, 1(1), 13-21. DOI:10.108o/o9765239.2010.11884920.

Omodero, C. O. (2020). Capital Market Determinants and Market Capitalization in Nigeria. International Journal of Financial Research, 11(1), 462-473. https://doi.org/10.5430/ijfr.v11n1p462.

Omodero, C. O. (2020). Capital Market Response to Monetary policy shocks: Evidence from Nigeria. Academy of Accounting and Financial Studies Journal, 24(3), 1-11. DOI: 1528-2635-24-3-544.

Pilinkus, D. (2010). Macroeconomic indicators and their impact on stock market performance in the short and long run: The case of the Baltic States. Technological and Economic Development of Economy, 16(2), $291-304$. https://doi.org/10.3846/tede.2010.19.

Pierre, G. \& Danilo, L. (2017). Monetary policy, stock market and sectoral co-movement. Documentos de Trabajo, No. 1731. Bancode Espana, Eurosistema. Available at: http://www.bde.es.

Prabu, E.A., Indranil, B. \& Ray, P. (2019). Impact of monetary policy on the Indian Stock Market: Does the devil lie in the details? Indian Institute of Management Calcutta. Working paper Series, WPS No. 822/March, 2019.

Rifat, A. (2015). Impact of monetary policy on stock price: Evidence from Bangladesh. Journal of Investment and Management, 4(5), 273-284. DOI: 10.11648/j.jim.20150405.29.

Santanu, P. \& Garg, A.K. (2019). Macroeconomic surprises and stock responses - A study on Indian stock market. Cogent Economics and Finance, 7, 1-31. https://doi.org/10.108o/23322039.2019.1598248.

Teja, K. R., Tejaswi, M., Madhavi., \& Ujwala, G. (2013). Cash Reserve Ratio impact on Stock Market (India) in Long run. International Journal of Marketing, Financial Services E Management Research, 2(8), 85-93.

Trung, T.N., Thi, L.D. \& Van, D.N. (2016). Impacts of monetary policy and information shock on stock market: Case study in Vietnam. International Journal of Economics and Finance, 8(7), $132-139$. http://dx.doi.org/10.5539/ijef.v8n7p132.

Vladimír, P. (2017). Effect of Money Supply on the Stock Market. Acta Universitatis Agriculturae et Silviculturae Mendelianae Brunensis, 65(2), 465-472. https://doi.org/10.11118/actaun201765020465.

Zare, R., Azali, M. \& Habibullah, M.S. (2013). Monetary policy and stock market volatility in the ASEAN5: Asymmetries over Bull and Bear Markets. Procedia Economics and Finance, 7, 18-27. Doi: 10.1016/S22125671(13)00213-X. 